\title{
Hepatodiaphragmatic Nodule
}

National Cancer Institute

\section{Source}

National Cancer Institute. Hepatodiaphragmatic Nodule. NCI Thesaurus. Code C120889.

A cong enital abnormality found in Fisher 344 rats characterized by grossly visible nodule(s) usually located on the median lobe of the liver. 